\title{
Gloss discourse as a gender tool of consumer motivation in the era of digital communications
}

\section{El discurso del brillo como una herramienta de género para la motivación del consumidor en la era de las comunicaciones digitales}

\author{
Aleksandra A. Vorozhbitova \\ alvorozhbitova@mail.ru \\ https://orcid.org/0000-0003-0023-5582
}

Doctor of Philology, Doctor of Pedagogy, Professor, Honorary Worker of Higher Professional Education of the Russian Federation, Professor of the Department of Romano-Germanic and Russian Philology, Sochi State University, Sochi, Russia.

\section{Zulima Z. Bzegezheva}

zulima@yandex.ru

https://orcid.org/0000-0001-8299-1263

Ph. D. of Philology, Associate Professor, Associate Professor of the Department of Romano-Germanic and Russian Philology, Sochi State University, Sochi, Russia.

Anastasia A. Buryanova steisy_adel@mail.ru

https://orcid.org/0000-0001-9066-2822

Senior lecturer of the Department of Romano-Germanic and Russian Philology, Sochi State University, Sochi, Russia.

Lyudmila V. Prus

idetvolna@mail.ru

https://orcid.org/0000-0003-2149-724X

Ph. D. of Pedagogy, Associate Professor, Associate Professor of the Department of Romano-Germanic and Russian Philology, Sochi State University, Sochi, Russia.

Recibido: $23 / 05 / 21$

Aceptado: 09/07/21

\section{Abstract}

The purpose of the article is to characterize the glossy magazine discourse (GMD) of the early 21 st century as a powerful tool for influencing the recipient in a situation with prevailing digital communication and electronic advertising, as a special discursive process that acts as an explicit tool of globalization.

The phenomenon of creating consumer motivation for predictable purchasing behavior, which is influenced by print and electronic glossy magazine discourse, is analyzed from the standpoint of the Linguistic and Rhetorical (L\&R) Paradigm of the Sochi scientific 
school. The authors suggest an original synergetic methodology combining the methods of linguistics, new rhetoric, pedagogy, psychology and economic management emphasizing the novelty of this discourse in the context of its influence on the formation and transformation of the modern linguistic personality.

It is concluded that this type of discourse, the latest in terms of chronology of the historical process, actualizes the polyethnic sociocultural \& educational space of the early 21 st century at a new level (on the example of Russia).

It is proved that GMD stimulates transformations in line with the leading trend of the formation of a "planetary linguistic personality" with the value orientations of the "philosophy of glamour".

Keywords: Linguistic and Rhetorical (L\&R) Paradigm, Sochi L\&R School, glossy magazine discourse (GMD), consumer motivation.

\section{Resumen}

El artículo considera que el discurso de las revistas de moda de principios del siglo XXI es una poderosa herramienta para influir en el destinatario en una situación en la que prevalecen la comunicación digital y la publicidad electrónica. Los autores analizan el fenómeno de crear motivación del consumidor para un comportamiento de compra predecible, que está influenciado por el discurso de las revistas impresas y electrónicas (GMD), considerado desde el punto de vista del Paradigma Lingüístico y Retórico (L\&R) de la escuela científica de Sochi. Este tipo de discurso es un proceso discursivo especial que actúa como una herramienta explícita de globalización. Los autores proponen una metodología sinérgica original que combina los métodos de la lingüística, la nueva retórica, la pedagogía, la psicología y la gestión económica, enfatizando la novedad de este discurso en el contexto de su influencia en la formación y transformación de la personalidad lingüística moderna. La relevancia de la investigación se enfatiza por el hecho de que el discurso de las revistas de moda es el más reciente en términos de cronología del proceso histórico. Además, el artículo actualiza el espacio sociocultural y educativo poliétnico de principios del siglo XXI, basándose en el ejemplo de los discursos de las revistas electrónicas en Rusia. Por primera vez, el papel del discurso de las revistas de moda se considera en el contexto de una transformación estimulante en línea con la tendencia principal de la formación de una "personalidad lingüística planetaria": la globalización basada en las orientaciones de valor de la "filosofía del glamour".

Palabras clave: Paradigma lingüístico y retórico (L\&R), Escuela L\&R de Sochi, discurso de revista brillante (GMD), motivación del consumidor.

\section{Introduction}

The concept of "discourse of glossy magazines" (a type of media discourse as an institutional one) covers various types of publications, including youth, thematic, etc., and acts as a generic concept in relation to the type of discourse we are studying, which we have nominated as a "glossy magazine discourse" (GMD). Being genetically secondary 
and derived from the female GMD, the male GMD develops more actively and has undergone an evolution in the content-semantic aspect (invention, or more broadly logos-thesaurus-inventive enrichment), while women's glossy magazines have largely remained at the same level of the frozen inventory scheme "following fashion and style trends as a dominant lifestyle". Women's magazines are mainly focused on fashion and style, in our opinion, they do not actually have a lifestyle as such, namely as a philosophical and ideological position, which distinguishes men's gloss (Khachmafova, Karabulatova, Luchinskaya \& Osipov, 2015).

Advertising discourse and "Public Relations (PR)" discourse are constitutive segments of GMD. The general and different characteristics of advertising and PR types of discourse are interpreted in our work as integral and differential features of two "discursive superstrata" that interact both with each other and with the "discursive substrate" of media discourse, its entertainment and information genre-style variety of GMD. The presence of advertising and PR types of discourse, and in the "interpenetrating mode", is an integral attribute, a constituent characteristic of the GMD, one of its essential features, genreforming components. It is the interaction of the three leading discursive sub-layers-media, advertising and PR-that generates a synergistic effect of a massive complex psychological impact on the collective recipient. At the same time, the dominance of advertising and the dictate of the advertiser have both direct and indirect influence on the formation of the recipient's gender ideal as a member of the consumer society of the "glossy sample" (Saenko, Sozinova, Karabulatova, Akhmetov, Mamatelashvili \& Pismennaya, 2016).

The Genesis and functioning of the gender-oriented glossy magazine discourse confirm its status as a discursive process, first, relevant (i.e., the latest in the historical perspective), and second, actualizing-in terms of values and worldview - the polyethnic sociocultural \& educational space of Russia at the beginning of the XXI century. GMD represents the "lifestyle" concept sphere - precisely as a media sphere, with a shift in emphasis in the "glossy" sense. Accordingly, we use clarifying constructions in the name: the media concept sphere "lifestyle" - "gloss" in the naive picture of the world, or the English-language interspersed "lifestyle".

The GMD thesaurus software captures the constantly multiplying attributes of the "beautiful life" advertised by the corporate language personality of the generalized GMD producer within the promoted style / lifestyle. The subject components of the latter at the level of one journal discourse practice are:

1) editorial board:

1.1) creative group (s);

1.2) performing journalists);

2) advertiser (s). 
The purpose of this article is to present the results of a study of actual discursive process in the context of globalization polyethnic sociocultural \& educational space, for example a glossy magazine discourse practices of Russia, which is relevant also for other countries of the CIS and world community in General. Modifications of modern gender ideals generated by the GMD are introduced into the public consciousness and reconstructed by us in the dialectical relationship of goals, two subject positions: 1) producer: to introduce into the language consciousness of the collective recipient the ideological foundations of a specific "glossy", glamorous lifestyle, a super-task - the commercial success of the implementation of its material attributes; 2) recipient: join the elite (in this case, in the glamorous vector of their evolution) canons of style and life values to improve their social status, meet their informational and "entertainment" needs.

\section{Materials and methods}

The research is based on collections of glossy magazines in Russian: for men - "FHM", "GQ", "Maxim", "Men's Health", "Bear"; for women - "Glamour", "Cosmopolitan", "Vogue"; analyzed more than 1000 contexts, minimally coherent in meaning.

Within the framework of the integrative methodology of the Linguistic and Rhetorical (L\&R) Paradigm of the Sochi scientific school, the following methods were used in the research process: descriptive, comparative, structural-semantic, distributive, interpretative, quantitative; contextual, conceptual, discursive, intertextual analysis; various types of reading; observation; description; paraverbal, verbal and reference correlation; iconic and speech distribution; L\&R reconstruction.

When analyzing the discourse, the aspect of compliance with the needs of the collective recipient as a genre-sociostratic segment of the mass readership (Valeeva, 2018) represents the "addressee factor", which ensures the functioning of the second part of the linguistic-rhetorical-hermeneutic circle in a glossy discourse ensemble, this aspect takes on its own characteristics. It is possible to concretize linguistic rhetorical (LR) pragmatics of GMD as follows: satisfaction of activity-communicative needs, interests, motives of receptive speech act of the generalized recipient.

At the same time, the semantics and syntactics of GMD, as well as other semiotic aspects of the discourse-text-forming process, are most subordinate to the leading pragmatic goal, strategy and tactics of the "glossy journalist" as a professional language personality in this type of discourse.

The recipient acts as a kind of "reflecting" subject of discourse, at first glance, passive, but he builds in an individual system of mental projections at the level of internal speech his receptive discourse- interpretation.

The latter passes into the reproductive-constructive and productive-creative registers of the discursive-text-forming process in the active mode of correspondence with the 
๔eduweb

Revista de Tecnología de Información y Comunicación en Educación • Volumen 15, Nㅜ 2. Mayo-agosto 2021

editorial Board, exchange of impressions with other readers, including using new information technologies - by participating in discussions on the website of a particular magazine.

\section{Results}

The theoretical analysis of scientific sources devoted to the study of the problem of gender in glossy magazines in one aspect or another (Dekich, 2018; Samotuga, 2012; Vorozhbitova, Karabulatova, Bzegezheva, Druzhinina \& Pyankoval, 2019), being understood in line with the Linguistic and Rhetorical Paradigm, allows us to identify such characteristics and essential features of the modern Russian GMD as:

1. at the level of logos-thesaurus- inventive parameters of the discursive process:

- publishing magazines on the terms of franchising as Russian-language versions of Western publications with the inevitable introduction of an polyethnic sociocultural \& educational space into the Russian mentality, into the historically formed mentality of the Russian language personality;

- the secondary nature of creative self-actualization of the generalized discourse producer as a corporate language personality, professional language personality of a "glossy journalist", the predominance of the reproductive and constructive register of speech-thinking activity;

- positioning, manipulation and introduction in public consciousness of the media concept sphere "lifestyle" (understand how lifestyle glossy or "luster"), which, thus, becomes relevant and dominant concept thesaurus determinants of collective linguistic personality of ethnic group in a given historical period of development of society, taking root in his plots aggregate linguistic personality of ethnosocial and, more specifically, soziokulturellen the language identity of the recipient is glossy discourse of the ensemble.

- gender orientation, i.e. the presence of a binary opposition of women's glossy magazines as primary discourse practices and men's glossy magazines as secondary discourse practices, which are derived, but have their own characteristics in the content and semantic aspect.

2. at the level of pathos-verbal-eloquent parameters of the discursive process:

- hypertext character inherent in the media text and media discourse as such, but maximally enhanced within the subgroup of print media in terms of colorfulness of images and the inclusion of tactile sensations (glossy surface and paper density);

- interactivity as an additional method of communicative influence on the recipient, i.e. including him in the circle of direct communication with editorial representatives by publishing readers ' letters, awarding prizes for winning various competitions, etc.;

- precedent in conjunction with the language game as the principles of forming headlines that actualize the reader's attention and include it in the desired ethno-socio- 
cultural context, affect mnemonic mechanisms and indirectly stimulate the motivational level of the recipient as a potential consumer of advertised goods and services.

3. at the level of ethos-motivational-dispositive parameters of the discursive process:

- initially globalizing and intensely globalizing (taking into account the continuous growth of the readership due to the change of generations) character;

- the expression of the ideological mission of the GMD: the formation and introduction into the public consciousness of the collective linguistic personality of the mass recipient of ethical principles, moral norms and moral attitudes of the philosophy of glamour, which goes back to the worldview platform of Epicureanism;

- purposeful application of appropriate models of masculine and feminine gender ideals, formed on the worldview platform of the philosophy of glamour, as tools for influencing the collective linguistic personality of the Russian ethnic society and its formation as an ideal "citizen of the glossy sample" of the information society of the XXI century.

Based on the results of the research, as a starting theoretical platform for further in-depth analysis of the iconic and verbal, including the actual text, components of the discourse ensemble under study, we have identified, using the concepts and terms of the L\&R Paradigm, the following typological features and essential features that characterize the GMD:

- a typological variety of GMD within the media discourse as a whole - creolized discourse, i.e. syncretically combining an attributive and iconic component (first of all, artistic photographs of advertised and promoted goods, services, legal entities and individuals) and a verbalized component (an essential feature of the dispositivesemiotic organization of GMD). At the same time, there is a clear dominance of the first one, taking into account the presence of transitional variants based on it as a substrate, in which verbal inclusions (superstrat) in the attribute-iconic component are presented at different levels.

These inclusions: 1) the names of the company / brand, label, brand, i.e. the levels of the word, phrase, and 2) advertising slogans, mottos of a particular product as an attribute of the promoted lifestyle, i.e. the level of the sentence (in the language aspect) implemented by a single phrase (in the speech aspect). As an additional means of communicative influence, along with iconic and verbal components, there is a tactile component or factor.

As essential features of the dispositive-architectonic organization of the GMD, we call the following:

- periodicity (magazine issues are published, as a rule, once a month) as a characteristic of the dispositive-temporal organization of individual representatives- 


\section{Geduweb}

Revista de Tecnología de Información y Comunicación en Educación • Volumen 15, № 2. Mayo-agosto 2021

issues of this discourse practice, female or male, within the framework of a glossy discourse ensemble;

- formation of a specific "glamorous / glossy" lifestyle as an ideal goal, representation by iconic and verbal means of the ideology of a glossy magazine discourse ensemble based on the essential principle of subordination of the ethos, logos and pathos of women's and men's discourse practices as prolonged speech acts of morality and philosophy of glamour);

- the highest printing quality, which at the semiotic level can be attributed to an essential feature from the sphere of pathos-semantic-eloquent parameters. At the same time, the carriers of semantics are both the verbal component and, above all, the paraverbal ones: iconic and tactile. In this regard, elocution in the semiotic aspect in relation to polycode, creolized discourse and gloss text, complicated by a tactile component, can be understood broadly. This is not just a "language design" of the content of the utterance, but its design by the whole complex of means of formal expression of the value-worldview and content-semantic aspects of the discourse text. Thus, in terms of discussion, the following variants and subtypes of elocution as the third part of the universal ideo-speech cycle "from thought, image, experience, and sensation to their representation" can be contrasted, from the standpoint of an extended understanding of "semiotic rhetoric" as "image rhetoric" (i.e. not only "from thought to word" in the classical sense of rhetoric): 1) verbal eloquence; 2) paraverbal eloquence: 2.1) the elocution iconic (visual language of artistic images, widely represented in the materials DB); 2.2) the prosodic elocution (presented in audioverse media); 2.3) elocution-level tactile perception, peculiar to the printing options of DB.). However, we emphasize that in the sphere of GMD, where magazine sites include, in particular, videos with models as a continuation of erotic photo sessions, music video reviews and video interviews with stars, these phenomena should be qualified as an Internet discourse based on a particular glossy discourse practice, i.e. a broader concept than GMD.

From the point of view of representation / in the parameters of the characteristics of functional speech styles (colloquial and book: scientific, official-business, journalistic, artistic) of the GMD, the main one is publicistic, being implemented in interviews, reviews, notes and articles, in which it sometimes evolves into scientific-journalistic (relatively speaking), which is due to thematic features (technology / culture).

From the point of view of the essential characteristics in the aspect of functional and semantic types of speech in the analysis of this discursive layer as a whole, we formulated the following essential feature in the aspect of the formation of discursive blocks: the dominance of the model of the functional and semantic type of speech "description". This property of the GMD is realized at the intersection with the universal from the sphere of the actual division of the sentence (the selection of the topic and rhema), which is legally transposed to the level of discourse. As the results of the analysis have shown, the global dominant concept "lifestyle" ("gloss") acts as the subject of the description, which demonstrates the unity of the topic and is system-forming in the aspect of the General architectonics of the referent. This "discourse concept" is characterized through a 
potentially infinite, but thematically limited number of attributes of the promoted glamorous lifestyle of the ideal member of consumer society. Taking into account the dichotomy at the level of speech universals - the categories "theme and rhema" - we qualify them as rematic discursive components. Based on observations of the specifics of the empirical material, it is legitimate to extrapolate the types of intra - text communication-chain and parallel-to the GMD. As the results of the analysis of the discursive layer of the studied glossy magazines have shown, at the level of General architectonics, it is possible to state a predominantly parallel connection of discursive blocks. In the center of attention (both the producer and, respectively, the recipient of GMD) as the organizing core is the same global theme - "lifestyle" (glossy lifestyle), which is revealed through numerous rematic components that carry information about its many specific material attributes (iconicverbal complexes with a tactile component). In the verbal block, non-material values are also affected to some extent - love, happiness, satisfaction from success in the chosen career field, psychological balance, etc., which are inextricably linked, directly or indirectly, with advertised consumer goods, services, including travel, psychoanalysis sessions with a specialist, etc.

"The factor" target audience in terms of the characteristics sociocultural language personality of a generalized recipient of this type of discourse allows to distinguish several groups of potential recipient GMD: "elite society" in the parameter of material well-being: the super-rich and rich people; 2) representatives of the secular elite: the media persons, stars of show business, stage, movies, sports, journalists, etc. (in the magazine gloss, news from their life, interviews, various popularity ratings, top 100, etc. are frequent); 3 ) the middle class; 4) the border layer of the population (including young people), seeking to improve their social status; see, for example: (Koryakovtseva, Doronina, Panchenko, Karabulatova \& Abdullina, 2016).

The essential features and typological features of GMD are systematically presented by us at a higher theoretical level through the prism of the L\&R paradigm. Generally speaking, GMD is distinguished, first of all: visibility, combination of verbal and iconic means of influencing the recipient with the dominant role of non-verbal and subordinate function of verbal components (eloquence of a special type, verbal-iconic, construction of tropes and figures at the level of visual iconic series (pathos-verbal-eloquent parameters); features of the thematic content of glossy magazine discourse practices: an inventive grid based on the attributes of a rich "beautiful life", forming a potentially infinite, only relatively coherent, but integral in value-worldview, content-semantic and formal-structural relations of the discourse.

\section{Discussion}

The speech-thinking activity of a professional language personality of the corporate type, its General LR strategy and specific tactics are stimulated by the advertiser-the customer of advertising and PR campaigns, who is interested in promoting their products and services and pays for advertising and PR blocks as ideologically and conceptually dominant, dominant blocks within the General semiotic field of GMD. Accordingly, in the 
Gduweb

Revista de Tecnología de Información y Comunicación en Educación • Volumen 15, Nㅜ 2. Mayo-agosto 2021

aspect of considering the "addressee factor" the phenomenon of GMD appears as a crystal structure of a synergistic nature that organizes the recipient's speech-thinking activity, which turns its various facets in the process of socio-cultural communication (Vorozhbitova, Karabulatova, Bzegezheva, Druzhinina \& Pyankoval, 2019; Khachmafova, Karabulatova, Serebryakova, Zinkovskaya \& Ermakova, 2017). All of them are aimed at one point as a strategic goal of a psycholinguistic nature for this discursive process: the translation of signals of visual-figurative and verbal-logical thinking, in their interaction and complex impact on the subconscious and consciousness of the recipient, into impulses of subject-effective thinking for the acquisition of one or another attribute of the promoted lifestyle (or, depending on the social status and financial situation of the recipient, taking a consumer loan, performing the initial act of accumulating funds for the purchase of this thing, etc.) (Rud', 2019). At the same time, for a large part of respondents who only seek to obtain the status of the middle class, the content of GMD can also become a source of frustration due to unsatisfied ambitions, a sense of hopelessness due to the inability to achieve a glossy standard of living and a striking contrast between its attributes on glossy pages and the realities of everyday life surrounding the reader. We will give a General description of the second subject of the linguistic rhetorical hermeneutical circle, which we qualify as a socio-cultural language personality of the generalized recipient of the GMD. A perspective on audience from the standpoint of perception the collective linguistic personality of a reader of the magazine gives an understanding from the positions of the L\&R Paradigm, the impact of the GMD and corporate linguistic identity of his producer on the generalized linguistic consciousness of the recipient, the suggestive potential of the type of discourse.

As a justification for the above thesis regarding types of thinking, we will give the following reasoning. Analysis of specificity of functioning of the advertising and PR types of discourse as podcasts of DB on the example of Russian women's and men's magazines of the XXI century allows to conclude that an Arsenal of strategies and tactics, methods of exposure GMD on the recipient operates on the levels of different kinds of thinking that can be spread from the point of view of "input", "assimilation" and "output" entering the mind of the reader the following information:

1) visual-imaginative thinking is activated already "at the entrance" of the structural levels of the recipient's perceiving language personality (mainly the linguocognitive level, or thesaurus, as well as, indirectly, the motivational level, or pragmaticon). This type of thinking generally prevails in this type of discourse and is decisive in terms of its suggestive impact (as is known, glossy magazines "do not read, but watch"; see, for example: (Zinovieva, 2018)), permanently updated throughout the entire process of perception of a glossy magazine;

2) verbal-logical thinking (which corresponds to the level of associative-verbal network, or $A B C$, in the structure of a language personality) is activated in the course of further actualization of various aspects of the formal-content-value unity of a particular issue of the journal as a separate dispositive segment of this discourse practice, while the primary reference points, milestones for perception, are the headings of materials. 
Within the framework of the GMD as a whole, verbal-logical thinking plays an auxiliary and additionally suggestive role (arguments to ethos, to logos, to pathos, arguments to the obvious, arguments "ad rem" and "ad hominem" in their consumer-glossy refraction), which is enriched and supported by various verbal means of persuasion in the course of rhetorical argumentation. However, in relation to the verbal block of the GMD, in the aspect of influencing the visual-imaginative thinking of the recipient, we note that language also draws images and, in a state of discursive actualization, affects the entire Arsenal of tropes and figures on the perceiving language personality. 3) subject-effective thinking of the recipient is activated to a greater extent "at the output" of the perceived information (mainly at the level of pragmatics in the structure of the language personality). This type of thinking is driven by a consumer in his or her specific desire to buy one or the other attribute is the material representative established in his mind through the GMD concept sphere "lifestyle" ("gloss", "lifestyle") - "on the subtle plane", but also in real actions consumers of goods and services "physics" - immediate or delayed, depending on the financial situation at the moment, the nuances of tastes and preferences.

Linguistic and rhetorical specificity of the speech-thinking process of a journalist as a professional language personality in this type of mass media is expressed in the formation of an invariant core and variable components of gender-ideal models in the discourse of the Russian gloss (Karabulatova, Vildanov, Zinchenko, Vasilishina, \& Vassilenko, 2017). From the point of view of three basic mechanisms for the implementation of professional LR competence of a journalist: inventive-paradigmatic, dispositive-syntagmatic, elokutivno-expressive - the system of inventive text actions of the discourse producer organizes a number of characteristics of the discourse text derived from the classical communicative qualities of speech.

Thus, the inventive-paradigmatic mechanism for implementing the LR competence of a GMD producer provides such communicative qualities as: 1) content and semantic saturation; 2) information content-in the aspect of novelty and diversity of representations of information about a wide range of objects, subjects, phenomena and processes under consideration; 3) completeness of coverage of the "real referent" in the system of its essential features and functional features; 4) objectivity (as a desire for it, achieved to a greater or lesser extent, taking into account the activity of the advertising and PRdiscourse sub-layers in the GMD), combined with the clarity of the personal position of the discourse producer as a consumer of a particular group of goods and services positioned as attributes of the promoted lifestyle (a specific journalist or group producereditorial Board, creative group); 5) accuracy in transmitting the characteristics and essential features of the referent with a pronounced pragmatic orientation in the aspect of forming a certain standard from the point of view of the editorial Board lifestyle and image of a modern successful person; 6) compliance with the needs of the collective recipient as a genre-sociostratic segment of the mass readership.

So, as a key figure - the direct producer of GMD - in the performer mode is a glossy magazine journalist who, in unbroken unity with advertisers, forms gender-oriented 
¿eduweb

Revista de Tecnología de Información y Comunicación en Educación • Volumen 15, № 2. Mayo-agosto 2021

content that creates a favorable ground for introducing into the recipient's consciousness, at the level of all types of thinking - visual-figurative, verbal-logical, subject-effective (see more below) - the needs for the possession of material values inherent in the described lifestyle of men and women as elite, the lifestyle of a select circle, the "cream of society".

GMD appears from the positions of the L\&R Paradigm as a discursive process, first, the latest (latest in terms of chronology of the historical process), and secondly to update the polyethnic sociocultural \& educational space of Russia beginning of the XXI century (stimulating its transformation in line with the trends of globalization and value orientations "philosophy of glamour").

In each named discourse practice (i.e., having a proper name - "Maxim", "Glamour", etc.), it is legitimate to interpret the magazine's No. 1 as a "mother issue": it explicates and objectifies the concept of the magazine (creative group) for the first time. Subsequent \# 2, 3, $4 \ldots \mathrm{n}-$ "children", child constructs that are quite similar, similar typologically in terms of dispositive framework (parts, categories, subheadings, methods of rhetorical promotion) and eloquent content (idiolect, idiostyle, manner of communication with readers of the corporate language personality of this editorial Board), but having individual features in terms of specifics of content and semantic content of the inventive grid.

In the era of digital technologies, the "information-intelligent personality" (IIP) concept that was proposed by S. E. Shilov has become relevant (Shilov, 2013). This is a kind of abstraction, reconstructed from the whole set of discourse practices of electronic communication. Publication numbers as components of one named micro- IIP - a kind of "brothers"(male gloss) and" sisters "(female gloss), all more "Junior". We can also talk about "generations" of the same magazine - if possible, identify certain milestones that separate the relatively completed stages of its development in terms of qualitative changes or updates to the concept of this discourse practice (which may be due, for example, to the change of the editor-in-chief or the specifics of the "dashing 90's", 2000's and 2010's). Thus, the Russian GMD ensemble appears as an integral phenomenon, an "information and educational organism" that has its own "semiotic body" and egregor, a circle of recipients-admirers who communicate with a particular favorite magazine using the tools of social networks. We can speak about the educational function of GMD, along with the information function and the projective-worldview (in its consumer-glamorous modification) function as the leading one, bearing in mind the direct meaning (discourseetymon) of the word "education", namely: "image creation". In the context of our research, the latter is understood as modeling the gender ideal, developed in its inextricably correlated concept opposition "man - woman".

Let's imagine a single issue of a magazine, or a glossy magazine discourse-text as a kind of "living organism", "informational entity "that interacts with the recipient and is personally personalized (cf. appeals in readers' letters such as "dear Maxim", "favorite magazine") using one of the cognitive tools of the process of scientific knowledge - a metaphor, in 
this case, of the human body, using some anatomical terms from the source (Skulkin, 2014).

Gender-specific topics, for example: the choice of technological gadgets (male) // decorative cosmetics (female) - act as differentiating "sexual characteristics "of personalized "men" and "women" as nominal micro-segments of the "informationintelligent personality" (IIP). At the level of gender systems of the information organism of a particular GMD, content-semantic components function, dedicated to the topics "sex, relationships", " candid photo sessions "(male), corresponding to the recipient's gender (Smeyukha, 2012).

Based on the principle of analogy, it is legitimate to rethink for theoretical purposes and apply the "photographing" method used in school practice to distinguish between functional and semantic types of speech. Recall: if the referent of "can I take a picture" is like description and narration; if only one of the image description, need a series of images - a narrative; if the referent of "revenge" is like the reasoning and value judgment. This technique is logical to extrapolate to the entire type of railway. At the same time, "photographing" appears as the leading principle of the organization of this type of discourse, i.e. in the literal sense, namely: 1) artistic photography as a dominant of the GMD; 2) attributive and iconic block (including verbal intersperses) 3) the functionalsemantic type of speech "description" as the main one for GMD; 4) the frequency of fragments of the functional-semantic type of speech "value judgment" integrated into the description; 5) the presence of inclusions in the description of the types of speech "reasoning" and "narration".

We consider another essential feature of the GMD to be the fundamentally synergistic basis for the formation and functioning of the GMD. Described in General terms, the tools of visual-figurative, speech-thinking and thought-speech influence on the recipient from the GMD in the aspect of their focusing into subject-effective impulses actually have a synergistic nature, i.e. the sum of the influences of its components-factors, is something more than the influence of each factor separately.

During our research, we formulated the following LR principles of the organization, functioning and impact of GMD, namely:

1. The principles of formal organizational level of GMD:

1.1) principle of kaleidoscopic (exaggerated brightness, ingenuity in the layout of the various elements of non-verbal-visual, verbally-slogan and text blocks; game fonts, colors, angles, etc.);

1.2) the principle of multilayers, or "layer cake" (the presence of "discursive layers" advertising, PR and infotainment, i.e. journalistic types of discourse).

2. The principles of substantive and organizational level of GMD: 
2.1) the principle of fragmentation, or "a little about a lot" ("snatching" the actual moments of various aspects of the life of a successful member of a mass-consumption society); 2.2) the principle of "hands on the pulse" (presentation of fashionable, trending aspects with a focus on the youth environment-fashion, gadgets, sports, Hobbies, etc.; the flip side is the rapid "aging" of the "subpersonality" of each issue, since fresh and even striking content is already "yesterday" in a few issues).

Various aspects of the long-term comprehensive study of GMD are detailed and generalized, in particular, in the monograph of the Sochi L\&R School (Skulkin, Vorozhbitova, 2018).

The integrative L\&R Approach is used by the team of authors of the Department of Romance-Germanic and Russian Philology of Sochi State University for various types of discursive processes, including socio-political ones (see, For example: (Vorozhbitova, Potapenko, Berezovskaya, Lebedeva \& Kushkol, 2019; Vorozhbitova, Potapenko, Khachaturova \& Khoruzhaya, 2020; Vorozhbitova, Streltsova, Urakova \& Nessipbayeva, 2020).

\section{Conclusion}

The article allows to make the following conclusions:

1. Glossy magazine discourse (GMD) appears from the positions of the Linguistic and Rhetorical (L\&R) Paradigm as a process, first, the latest (latest in terms of chronology of the historical process), and secondly, to update the polyethnic sociocultural \& educational space of Russia at the beginning of the 21 century, in the era of digital communication, specifically affect (stimulating its transformation in line with the trends of globalization and value orientations "philosophy of glamour").

2. The modifications of the modern gender ideal are generated by specific linguistic and rhetorical organization of this type of discourse in its printed and electronic formats and are implemented in the public consciousness. These modifications are reconstructed in the dialectical correlation of the goals of the two subject positions:

1) producer: to introduce into the language consciousness of the collective recipient the ideological foundations of a specific "glossy", glamorous lifestyle; a super-task - the commercial success of the implementation of its material attributes;

2) recipient: join the elite (in this case, in the glamorous vector of their evolution) canons of style and life values to improve their social status, meet their informational and "entertainment" needs.

3. We can present GMD from the position of the birth and development of the discourse of the ensemble as a living organism, in an evolutionary and dynamic aspect of the discursive process relevant to the contemporary polyethnic sociocultural \& educational space of Russia at the beginning of the 21 century. The theoretical and methodological basis for this is the L\&R Paradigm, the concept of "information- 
intelligent personality" (IIP), and the biological conceptual and terminological system for describing the human body.

4. The establishment of organization of speech-thinking activity "glossy journalist" as a professional linguistic personality of an institutional type allowed to perform the categorical development of the concept of "corporate linguistic identity" with respect to generalized producer of GMD. In our concept, the corporate language personality of a generalized producer of GMD is formed by:

1) direct producer: the editorial Board of a particular glossy discourse practice, female or male, as a "group concept carrier", including such "active elements" as:

1.1) creative group(s);

1.2) writing journalists;

2) indirect producer: advertiser(s).

5. "The factor" target audience in terms of the characteristics sociocultural language personality of a generalized recipient of this type of discourse allows to distinguish several groups of potential recipient GMD: "elite society" in the parameter of material well-being: the super-rich and rich people; 2) representatives of the secular elite: the media persons, stars of show business, stage, movies, sports, journalists, etc. (in the magazine gloss, news from their life, interviews, various popularity ratings, top 100, etc. are frequent); 3) the middle class; 4) the border layer of the population (including young people), seeking to improve their social status.

6. The Essential features and typological features of GMD are systematically presented by us at a higher theoretical level through the prism of the L\&R Paradigm. Generally speaking, GMD is distinguished, first of all: visibility, combination of verbal and iconic means of influencing the recipient with the dominant role of non-verbal and subordinate function of verbal components (eloquence of a special type, verbal-iconic, construction of tropes and figures at the level of visual iconic series (pathos-verbaleloquent parameters); features of the thematic content of GMD practices: an inventive grid based on the attributes of a rich "beautiful life", forming a potentially infinite, only relatively coherent, but integral in value-worldview, content-semantic and formalstructural relations of the discourse.

7. At the end of the categorical development of the postulated concept, we formulated the final definition of GMD, presented in the first conceptual provision of the introduction, as well as LR principles related to various aspects of the organization, functioning and impact of GMD.

So, the combination of men's and women's glossy magazines with a thematic dominant style / lifestyle ("glamorous magazines") forms a subtype of mass media - glossy magazine discourse. The latter is defined as a gender-oriented discourse of glossy magazines that has an image-advertising and information-entertainment character, revealing the features of the lifestyle of a member of the consumer society of the information age from the standpoint of the "philosophy of glamour". The concept of 


\section{๔eduweb}

Revista de Tecnología de Información y Comunicación en Educación • Volumen 15, № 2. Mayo-agosto 2021

"discourse of glossy magazines" in relation to GMD is, therefore, generic and refers to various types of publications, including youth, thematic, etc.

In the static aspect, the text array of the Russian civil railway of the beginning of the 21 century is an independent discourse ensemble formed by two sets of discourse practicesmale and female.

In the dynamic aspect, GMD acts as a discursive process that actualizes the polyethnic sociocultural \& educational space by integrating and generalizing traditional and modern socio and linguistic cultural standards in the context of globalization; the mechanism of discursive actualization is the calculation of Western publications about lifestyle.

Thus, the media concept "LIFESTYLE", presented in the GMD, is not only a globalizing megaconcept, but also a trigger, an effective tool for the expansion of the processes of globalization in the conditions of electronic communication of the modern digital society.

\section{Reference}

Dekich, E. (2018). Gender stereotypes: content analysis of advertising in glossy magazines. The Age of Information, 2-1, 148-149.

Karabulatova, I., Vildanov, Kh., Zinchenko, A., Vasilishina, E., \& Vassilenko, A. (2017). Problems of transformation matrices modern multicultural identity of the person in the variability of the discourse of identity Electronic Information Society. Pertanika Journal of Social Science \& Humanities, 25(S), Jul., 1-16.

Khachmafova, Z. R., Karabulatova, I. S., Serebryakova, S. V., Zinkovskaya, A. V., \& Ermakova, E. N. (2017). The Specifics of an Estimate discourse of gender stereotypes in small forms of Folklore in a Network Discourse of Electronic and Information society at the Beginning of 21ct Century. Pertanika Journal of Social Science \& Humanities, 25 (S) Jul., 137-150.

Khachmafova, Z. R., Karabulatova, I.S., Luchinskaya, E. N., \& Osipov, G. V. (2015). Gender Features of Discourse of Woman's Literature as a Reflection of Changes in the Modern Society. MJSS, 6 (3), S 2, 476-481.

Koryakovtseva, O.A., Doronina, I.I., Panchenko, T.M., Karabulatova I.S., Abdullina, Z.M. (2016). Research of category "Motivation" as a basic tool of personnel management. IRMM, 6 (1), 293-299.

Arbeláez-Campillo, D.F., Andreyevna-Dudareva, M., Rojas-Bahamón, M.J. (2019). Las pandemias como factor perturbador del orden geopolítico en el mundo globalizado. Cuestiones Políticas, 36(63), 134-150.

Rud', A. (2019). Gender Stereotypes in the management and analysis of the main approaches to their study. Personality and society. Electron. nauch. journal, 1(1), 24.

Saenko, N. R., Sozinova, A. A., Karabulatova, I. S., Akhmetov, I. V., Mamatelashvili, O. V., \& Pismennaya, E. E. (2016). Research in Action Integrated Marketing 
Communications as the Elements of Information and Virtualization Market Relations. IRMM, 6 (1S), 267-272.

Samotuga, E. A. (2012). Linguistic and cognitive features of the discourse of glossy magazines: gender aspect: based on the material of the magazines "Cosmopolitan" for 2005-2011. Belgorod: Belgorod State University.

Shilov, S.E., (2013). Rhetorical number theory / S.E. SHilov. - M.: Lenand, 2013. 800 s. Skulkin O. V., \& Vorozhbitova A. A., (2018). Glossy magazine discourse in Russia of XXI century: linguistic-rhetorical parameters of gender ideal functioning: monograph. Sochi: RIC FGBOU VO "SGU", $176 \quad$ p, https://rusneb.ru/catalog/000200_000018_RU_NLR_BIBL_A_011783158/

Skulkin, O. V. (2014). Glossy magazine discourse in Russia of $X \overline{X I}$ century: linguisticrhetorical parameters of gender ideal functioning: autoref. Diss. ... Cand. Philol. Sciences, Sochi, https://www.dissercat.com/content/glyantsevyi-zhurnalnyidiskurs-v-rossii-xxi-veka-lingvoritoricheskie-parametry-funktsionirov

Smeyukha, V. V. (2012). The phenomenon of gender identification in the media space: on the material of domestic women's magazines. Autoref. Diss. ... Dr. Philol. Sciences. Krasnodar: KubSU, https://www.dissercat.com/content/fenomengendernoi-identifikatsii-v-mediinom-prostranstve-na-materiale-otechestvennykhzhensk

Valeeva, N. G. (2018). Translation theory: cultural-cognitive and communicativefunctional aspects. Moscow: RUDN Publishing House, 247.

Vorozhbitova, A., Karabulatova, I., Bzegezheva, Z., Druzhinina, V., \& Pyankova, T. (2019). A glossy magazine discourse of the early twenty-first century as a tool of globalization: Sochi school of linguistics and rhetoric. Amazonia Investiga, 8(24), 170-180. https://amazoniainvestiga.info/index.php/amazonia/article/view/969

Vorozhbitova, A., Potapenko, S., Berezovskaya, L., Lebedeva E. \& Kushko, N. (2019). Discourse of Communism and Socialist linguistic personality: Rhetorical perspective. Amazonia Investiga, 8(23), 739-748 https://amazoniainvestiga.info/index.php/amazonia/article/view/929

Vorozhbitova, A., Streltsova, M., Urakova, F., \& Nessipbayeva, Z. (2019). The role and place of language in social conflict // Advances in Social Science, Education and Humanities Research, volume 374. International Conference on Man-Power-LawGovernance: Interdisciplinary Ap-proaches (MPLG-IA 2019), Atlantic Press, pp. 204-207, https://www.atlantis-press.com/proceedings/mplg-ia-19/125925308; https://dx.doi.org/10.2991/mplg-ia-19.2019.41

Vorozhbitova, A., Potapenko, S., Khachaturova, N., \& Khoruzhaya, Y. (2020). Linguistic rhetoric of Soviet discourse: official vs personal register (J. Stalin - A. Dovzhenko). $\begin{array}{lllll}\text { Amazonia Investiga, } & 9 & \text { (29), 224-233 }\end{array}$ https://amazoniainvestiga.info/index.php/amazonia/article/view/1388

Zinovieva, E. S. (2018). Linguistic mechanisms of constructing masculinity and femininity in the discourse of glossy magazines: on the material of English and Russian languages. (Autoref. Diss. ... Cand. Philol.) Sciences Yaroslavl, https://www.dissercat.com/content/yazykovye-mekhanizmy-konstruirovaniyamaskulinnosti-i-feminnosti-v-diskurse-glyantsevykh-zhu 